\title{
HEAVY METAL ACCUMULATION IN SMALL TERRESTRIAL RODENTS INFECTED BY CESTODES OR NEMATODES
}

\author{
JANKOVSKÁ I.*, LANGROVÁ I.*, BEJCEK V.**, MIHOLOVÁ D.***, VADLEJCH J.* \& PETRTYL M.*
}

\section{Summary :}

The aim of the present study was to assess whether there is a difference in accumulation of heary metal ions $(\mathrm{Cd}, \mathrm{Cr}, \mathrm{Cu}, \mathrm{Mn}$, $\mathrm{Ni}, \mathrm{Pb}$ and $\mathrm{Zn}$ ) in hosts (small mammals) infected by cestode parasites when compared to those without cestode infection. The abundance of gastrointestinal parasites and bioaccumulation of heavy metals in host livers and kidneys were measured. Contents of heavy metals in hosts were determined by ICP OES method. The hosts with cestode infection (Paranoplocephala sp.) had lower contents of heavy metals in their livers and kidneys compared to hosts with nematode infection (Mastophorus muris). The content of $\mathrm{Pb}, \mathrm{Cd}, \mathrm{Cr}, \mathrm{Cu}$ and $\mathrm{Ni}$ was higher in kidneys than in livers, in both (cestode and nematode infected) rodents while the content of $\mathrm{Mn}$ was higher in livers. Content of $\mathrm{Zn}$ was similar. The content of heavy metals in host was decreasing with the increasing abundance of cestodes (Paranoplocephala sp.). Species-response models to particular heavy metals are presented.

KEY WORDS : bioaccumulation, $\mathrm{Cd}, \mathrm{Cr}, \mathrm{Cu}, \mathrm{Mn}, \mathrm{Ni}, \mathrm{Pb}, \mathrm{Zn}$, small mammals, rodents, cestode infection, nematode infection.

\section{INTRODUCTION}

W ild animals are normally exposed to heavy metals in their natural habitats. Since muscle tissue makes up the bulk of carnivorous diet, and biologically incorporated heavy metals are (in particular lead) transferred upwards in the food chain only with difficulties - the herbivorous species may be more susceptible to lead and other heavy metals poisoning than their predators (Kålås et al., 2000).

Parasites can be used as efficient indicators because of the variety of ways in which they respond to anthropogenic pollution (Sures, 2004). Wild animals are naturally exposed to basal levels of heavy metals in their natural habitats. Field studies have shown that high

\footnotetext{
* Department of Zoology and Fisheries, Faculty of Agrobiology, Food and Natural Resources, ${ }^{* *}$ Department of Ecology, Faculty of Environmental Sciences, **** Department of Chemistry, Faculty of Faculty of Agrobiology, Food and Natural Resources, Czech University of Life Sciences, Prague, Kamycka 957, 16521 Prague 6-Suchdol, Czech Republic.

Correspondence: Ivana Jankovská. Tel.: +420 224382793.

E-mail: jankovska@af.czu.cz
}

Résumé : ACCUMULATION DE MÉTAUX LOURDS CHEZ DES PETITS RONGEURS TERRESTRES ATTEINTS DE CESTODOSES OU DE NEMATODOSES Le but de cette étude était de savoir s'il y avait une différence d'accumulation d'ions de métaux lourds ( $\mathrm{Cd}, \mathrm{Cr}, \mathrm{Cu}, \mathrm{Mn}, \mathrm{Ni}, \mathrm{Pb}$ et $\mathrm{Zn}$ ) chez des petits mammifères atteints ou non d'une cestodose. La quantité de parasites gastrointestinaux et la bioaccumulation de métaux lourds aux niveaux du foie et des reins ont été mesurées. La présence de métaux lours chez les hôtes a été déterminée par la méthode ICP OES. Les hôtes porteurs de cestodes

(Paranoplocephala sp.) avaient des taux de métaux lourds dans leur foie et dans leurs reins plus bas comparés aux hôtes porteurs de nématodes (Mastophorus muris). Les taux de Pb, Cd, Cr, Cu et Ni étaient plus élevés dans les reins que dans le foie chez les les rongeurs porteurs de cestodes ou de nématodes, alors que les taux de Mn étaient plus élevés dans le foie et que ceux de $\mathrm{Zn}$ étaient similaires. Les taux de métaux lourds chez les hôtes diminuaient quand l'abondance de cestodes (Paranoplocephala sp.) augmentait. Des modèles de réponse des espèces à des métaux particuliers sont présentés.

MOTS ClÉS : bioaccumulation, $\mathrm{Cd}, \mathrm{Cr}_{1}, \mathrm{Cu}, \mathrm{Mn}, \mathrm{Ni}, \mathrm{Pb}, \mathrm{Zn}$, petit mammifère, rongeur, cestodose, nématodose.

levels of heavy metals in the environment may be monitored appropriately by the assessment of their concentrations in internal organs of free-living small mammals (Ieradi et al., 2003; Kålås et al., 2000).

Studies on endoparasites of fish revealed that several helminths were able to accumulate considerable concentrations of heavy metals (Schludermann et al., 2003; Sures 2001, 2003, 2004, 2006; Sures \& Siddal, 1999, 2001; Sures et al., 1999). There is lack of information on parasites of vertebrates living in terrestrial ecosystems as sentinels for heavy metal environmental pollution (Sures et al. 1998; Sures et al., 2000ab; Sures et al., 2002ab; Scheef et al., 2000; Torres et al., 2004).

High metal accumulation in worms (cestoda, acanthocephala) affected the metal levels in the tissues of a definitive host (Sures \& Siddal, 1999). The pollutants negatively affected chemical conditions in pedosphere (Han et al., 2002). The exposed ecosystems are also affected by other pollution components developing during combustion of low quality brown coal - such as nitrogen oxides, fluorides, heavy metals, radon. 
Coal industry represents one of the most important sources of environmental contamination with heavy metals. The dust emitted contains zinc, copper, lead and cadmium, and this contamination may increase the content of metals in the tissues of mammals inhabiting polluted areas. Rodents in our study were collected at a polluted area in Krusne hory (Northwest Bohemia, CR), where pollutants from petrochemical industries and brown coal power plants are common. We analyzed heavy metal levels in kidneys and livers of Microtus agrestris and Apodemus flavicolis in order to find out whether the levels had been affected by presence of cestode or nematode helminth parasites, respectively.

The purpose of this paper was to study the impact of the parasite burden on bioaccumulation of heavy metals in some tissues of small terrestrial rodents. The present study addresses effects of parasites (cestoda or nematoda) on heavy metal concentrations in field voles (Microtus agrestris) and field mice (Apodemus flavicolis) under field conditions.

\section{MATERIAL AND METHODS}

\section{SAMPLING AREA}

$\mathrm{F}$ ield research was conducted in the industrial immissions affected area of the Krusne Hory Mountains (approximately $30^{\circ} 42^{\prime} \mathrm{N}-13^{\circ} 36^{\prime} \mathrm{E}$ ), in northwestern Bohemia (Fig. 1), Sumny dul area (Fig. 2). Animals were sampled in the spring of 2003 (the beginning of June) on three quadrate grids (10 by 10 trapping points, span $10 \mathrm{~m}$ ) and along 10 trap-lines (50 trapping points, span $5 \mathrm{~m}$ ) using snap-traps. The quadrate grids and trap lines were situated in deforested habitats with dense growth of the reed-grass (Calamagrostis villosa) and a new plantation of tree species (the blue spruce, Picea pungens; European larch, Larix decidua; the mountain ash, Sorbus aucuparia) at an elevation of $750-850 \mathrm{~m}$ above sea level.

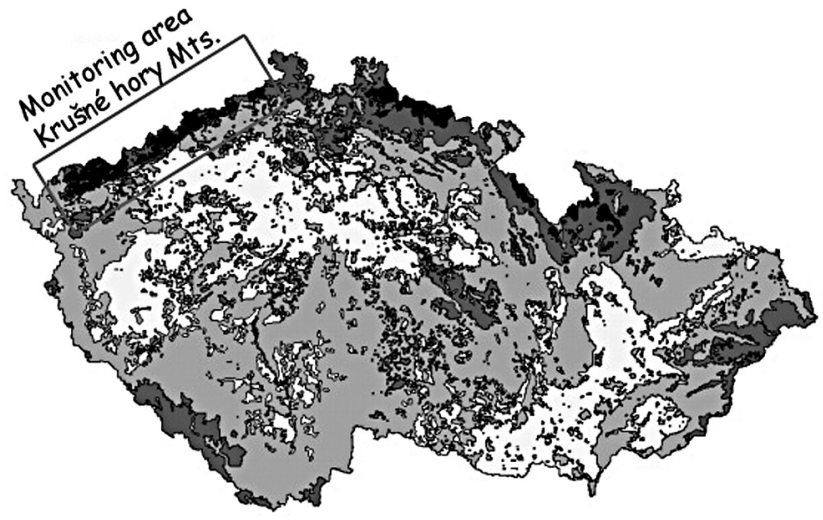

Fig. 1. - Sampling area: Krusne hory Mts., Czech Republic (black color represents area most affected by industrial immissions).

\section{CAPTURED ANIMALS}

50 terrestrial rodents (28 Apodemus flavicolis, 14 Microtus agrestris and 8 Clethrionomys glareolus) were trapped into snap traps. Trappings were made by using standard methods in permanent quadrates 1 ha. Dead animals were collected and stored in plastic bags and kept frozen $\left(-20^{\circ} \mathrm{C}\right)$ until laboratory analyses were performed. The animals were conditioned to $0^{\circ} \mathrm{C}$ before they were opened for removal of liver, kidneys and digestive tract. Digestive tracts were analysed for intestinal cestodes or nematodes. Parasitologically negative rodents and rodents with mixed infection (cestodes and nematodes together) were excluded from this study. Final material consisted of 25 small mammal specimens (15 Apodemus flavicolis, 10 Microtus agrestris) with nematode (Mastophorus muris) or cestode (Paranoplocephala sp.) infection, respectively (Table I). Host groups were made by putting together three (or four) rodents of the same sex, weight, age and parasite burden. Immature individuals (born in the year of capture) were considered juveniles, the overwintered mature individuals as adults. The caught animals were both males and females. Yellow-necked field mice (Apodemus flavicolis) were 69-92 mm long and weighed 15-

\begin{tabular}{clll}
\hline Sample & $\begin{array}{c}\text { Host } \\
\text { (number)* }\end{array}$ & Size, weight, sex & \multicolumn{1}{c}{$\begin{array}{c}\text { Helminth } \\
\text { (number) }\end{array}$} \\
\hline 1 & Apodemus flavicolis (3) & $69-73 \mathrm{~mm}, 15-18 \mathrm{~g}, \mathrm{~F}$ & $\begin{array}{l}\text { Mastophorus muris }(3 \times 3)^{* * *} \\
\text { Mastophorus muris }(3 \times 4)\end{array}$ \\
2 & Apodemus flavicolis (3) & $75-80 \mathrm{~mm}, 19-21 \mathrm{~g}, \mathrm{M}$ & Mastophorus muris $(3 \times 5)$ \\
3 & Apodemus flavicolis (3) & $83-85 \mathrm{~mm}, 22-23 \mathrm{~g}, \mathrm{~F}$ & Mastophorus muris $(3 \times 2)$ \\
4 & Apodemus flavicolis (3) & $86-89 \mathrm{~mm}, 24-25 \mathrm{~g}, \mathrm{M}$ & Mastophorus muris $(3 \times 6)$ \\
5 & Apodemus flavicolis (3) & $90-92 \mathrm{~mm}, 26-27 \mathrm{~g}, \mathrm{M}$ & Paranoplocephala sp. $(3 \times 2)^{* * * *}$ \\
6 & Microtus agrestris (3) & $95-99 \mathrm{~mm}, 22-30 \mathrm{~g}, \mathrm{M}$ & Paranoplocephala sp. $(4 \times 2)$ \\
7 & Microtus agrestris (4) & $100-104 \mathrm{~mm}, 31-35 \mathrm{~g}, \mathrm{~F}$ & Paranoplocephala sp. $(3 \times 3)$ \\
8 & Microtus agrestris (3) & $105-109 \mathrm{~mm}, 36-42 \mathrm{~g}, \mathrm{M}$ & \\
\hline
\end{tabular}

* Host groups were put together by tree (or four) rodents with the same sex, weight, age and parasite burden.

** Apodemus flavicolis (15) were infected with Mastophorus muris (3-6 nematodes in one field mouse).

*** Field voles (10 Microtus agrestris) were infected with Paranoplocephala spp. (2-3 cestodes in one vole).

Table I. - Helminths burden of small rodents used for heavy metal analysis. 


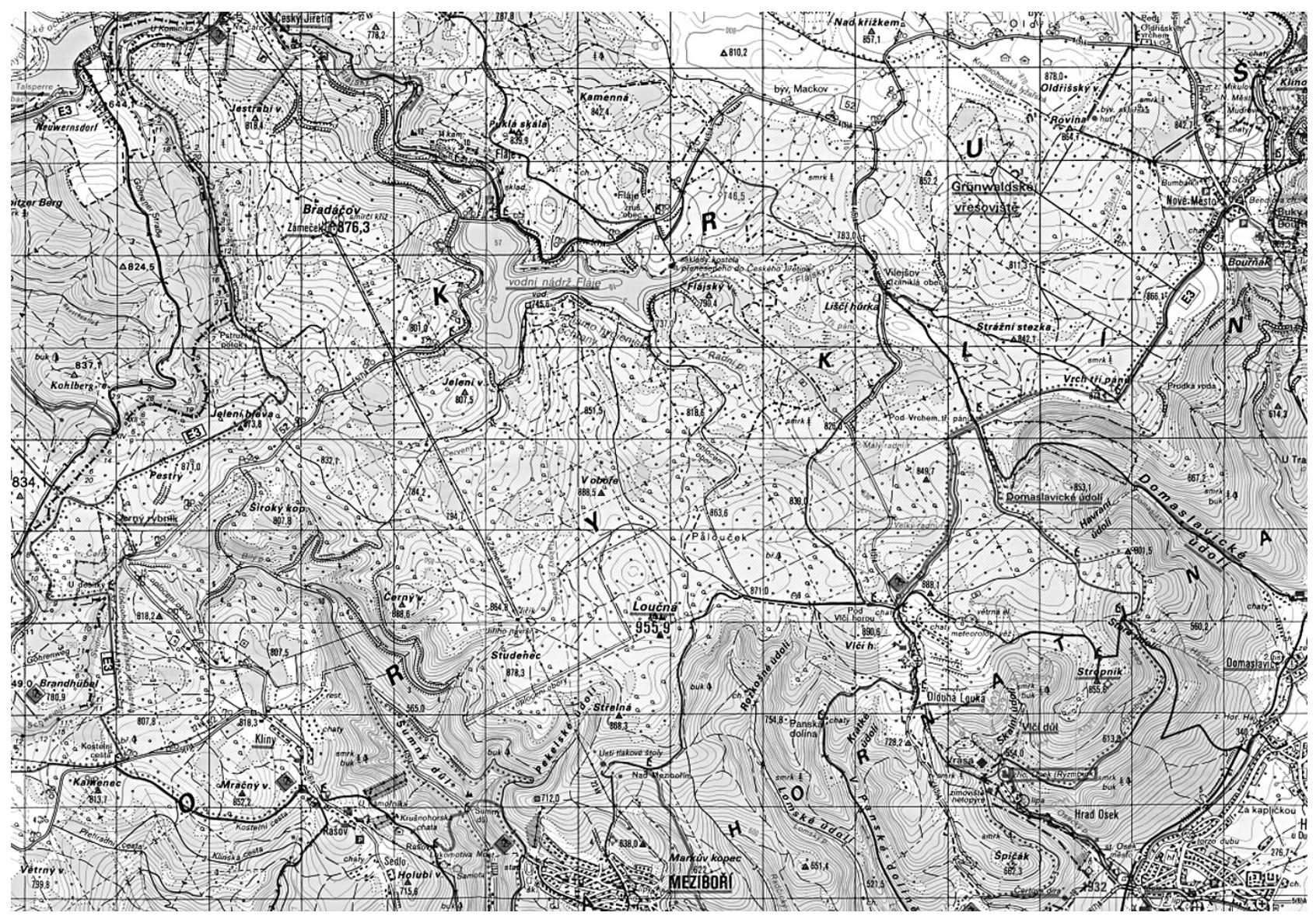

Fig. 2 - The detail of sampling area (Sumny dul).

$27 \mathrm{~g}$. Field voles (Microtus agrestris) were 95-109 mm long and weighed 22-42 g (Table I).

\section{ANALYTICAL PROCEDURE}

Liver and kidneys (each 0.2-5.0 g) were taken from each mammal and rinsed in double distilled water for one min. Heavy metals content (cadmium, chromium, copper, lead manganese, nickel and zinc) was determined in mixed samples formed from liver or kidney of 3-4 small mammals of each species (This procedure was used to prevent values under detection limit of analytical method for tissue of one host). Total number of the groups was 10 for liver and kidney, respectively (two groups with Clethrionomys glareolus were excluded from another investigation in this study).

Samples of tissues (0.2-5.0 g fresh weight) were dried at $105^{\circ} \mathrm{C}$ and then decomposed by dry ashing procedure described by Mader, Száková \& Miholová (1989). The procedure consists of these steps: charring of material in covered beakers on hot plate at $180-360^{\circ} \mathrm{C}$ for four hours, ashing at $350-500^{\circ} \mathrm{C}$ for three hours in muffle furnace and followed by ashing at $500^{\circ} \mathrm{C}$ for 14 hours. To remove organic matrix residue in ash $1 \mathrm{ml}$ of $65 \%$ nitric acid p.a. (Merck) was added as ashing aid and after the evaporation of acid the repeated ashing at $500^{\circ} \mathrm{C}$ for one hour proceeded. Final white ash was leached with $1.5 \% \mathrm{HNO}_{3}$ prepared from $65 \%$ nitric acid p.a. (Merck) and deionized water $\left(18 \mathrm{M} \Omega \mathrm{cm}^{-1}\right)$ (PCS Sybron Barnstead), with help of ultrasonic bath. The concentrations of analytes in the digests were measured by ICP OES technique using the instrument Varian VistaPro (Varian, Austalia). Standard solutions ASTASOL (Analytika, CR) of elements were used in the preparation of calibration curve for the measurement. Quality of analytical data was assessed by simultaneous analysis of certified reference material CRM 12-02-01 (Bovine Liver). Analytical blanks (20\% from all the samples) prepared by the same procedure, but without tissues, were used to determine the detection analytical limit. Samples of tissues were analyzed in two replicates.

\section{STATISTICAL ANALYSIS}

The Mann-Whitney U-Test (Mann and Whitney, 1947) was applied for the statistical analysis $(p \geq 0.05)$. All computations were done by using Statistica package version 7 (StatSoft, 2005). Contents of heavy metals (dried weight) in liver and kidneys were compared with paired $t$ test as the measurements came from the same 
individuals. All these analyses were performed within R (R Development Core Team 2004). Data on the abundance of parasites and the content of heavy metals were analyzed by multivariate methods using CANOCO (Ter Braak \& Smilauer 2002). Due to small sample size, only the main effects were investigated. Individual responses of parasites to particular heavy metals were first tested by Monte-Carlo permutation test with 499 permutations. Species, whose abundance was not significantly $(p<0.05)$ influenced by the content of any heavy metal, were omitted from the maximal model. Species responses to content of heavy metals of significant relationships were than modeled by using Generalized Linear Models (GLM) with Poisson errors.

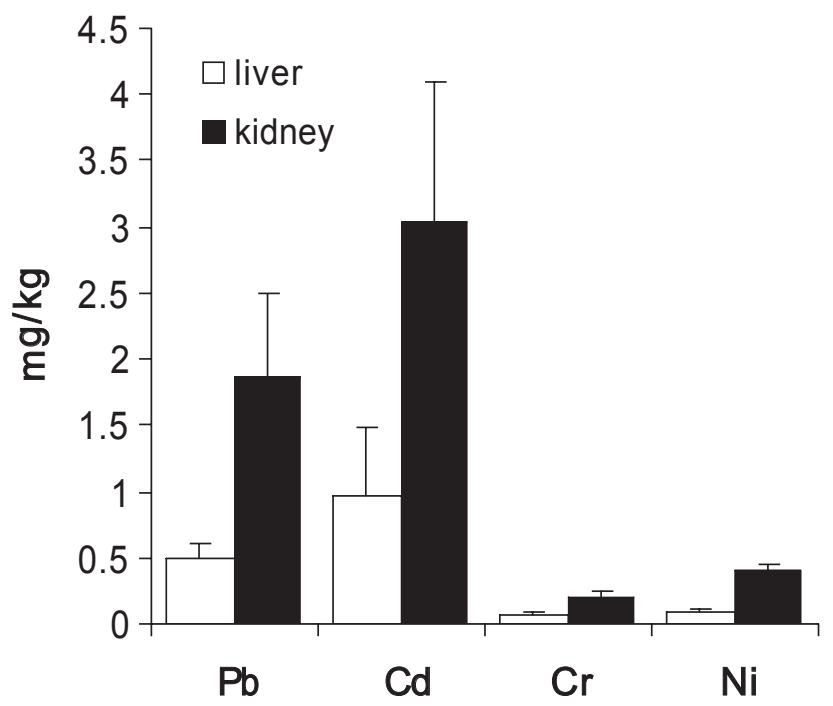

Fig. 3. - Comparison of the amount (mean $+\mathrm{SE}$ ) of $\mathrm{Pb}, \mathrm{Cd}, \mathrm{Cr}$ and $\mathrm{Ni}$ in the livers and kidneys of small mammals.

\section{RESULTS}

\section{HEAVY METALS ACCUMULATION IN HOSTS}

ignificantly higher contents of $\mathrm{Pb}, \mathrm{Cd}, \mathrm{Cr}, \mathrm{Cu}$, and $\mathrm{Ni}$ were found in kidneys than in liver (paired $\mathrm{t}$ tests, $\mathrm{t}_{12}<2.6, p<0.02$, Figs 3, 4). Mn content was, however, significantly higher in liver than in kidneys (paired t test, $\mathrm{t}_{12}=2.9, p=0.01$, Fig. 2). Content of $\mathrm{Zn}$ did not differ between liver and kidneys.

\section{PARASITE BURDENS}

Parasitologically negative rodents (5) and rodents with mixed infection - cestodes and nematodes together (20)

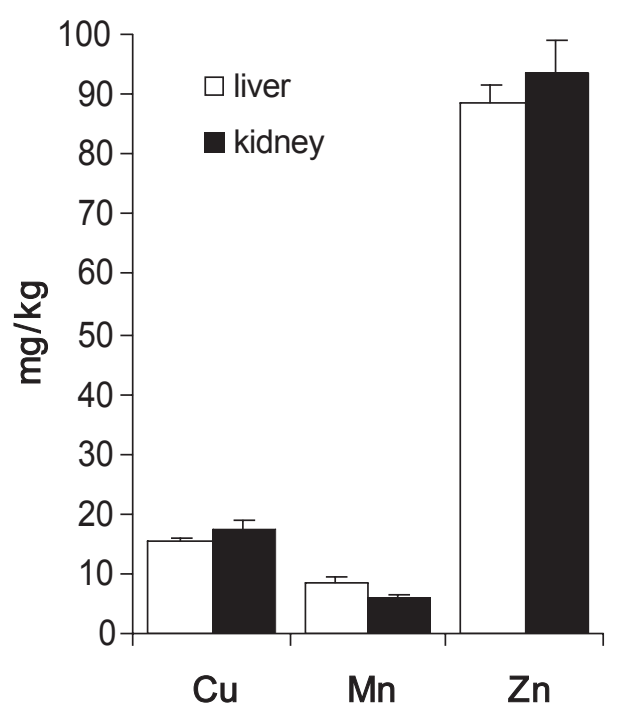

Fig. 4. - Comparison of the amount (mean $+\mathrm{SE}$ ) of $\mathrm{Cu}, \mathrm{Mn}$, and $\mathrm{Zn}$ in the liver and kidneys of small mammals.

\section{$\square$ infected by nematodes \\ - infected by cestodes}

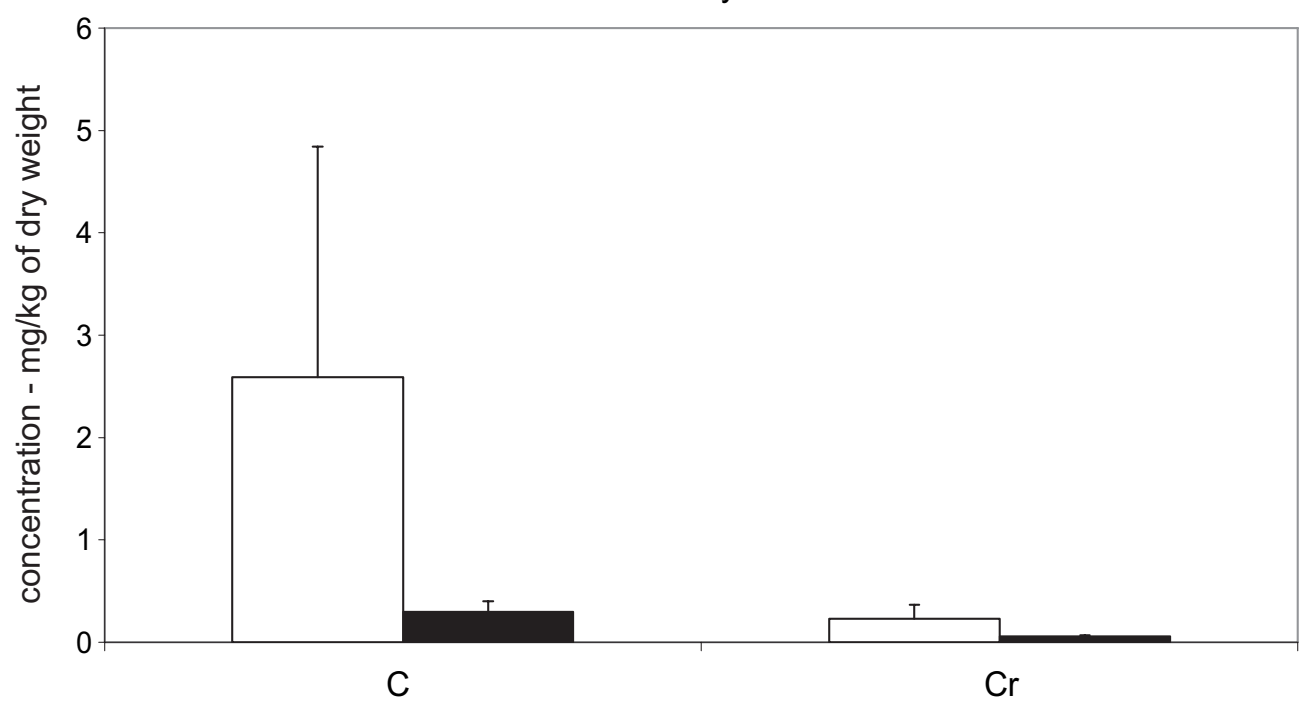

Fig. 5. - Means and standard deviations of obtained data shows $\mathrm{Cd}$ and $\mathrm{Cr}$ concentrations (dry weight) in kidney of rodents infected with cestodes or nematodes - elements where significant differences between nematode and cestode infected rodents were found. 
- were excluded from this study. The final material consisted of 25 small mammal specimens (10 Microtus agrestris and 15 Apodemus flavicolis, ) with cestode or nematode infection, respectively (Table I).

\section{PARASITE BURDENS AND HEAVY METALS ACCUMULATION}

Comparison of heavy metals content in livers and kidneys of rodents infected with cestodes or nematodes, respectively, shows that higher concentration of metal is, in general, in rodents infected with nematodes. However, this difference was not found to be significant in all elements (Mann-Whitney U-test, $p<0.05$ ). A statistically significant difference was found just in cadmium concentration $(p=0.032)$ and chrome concentration $(p=0.003)$ in kidneys. In both cases, higher
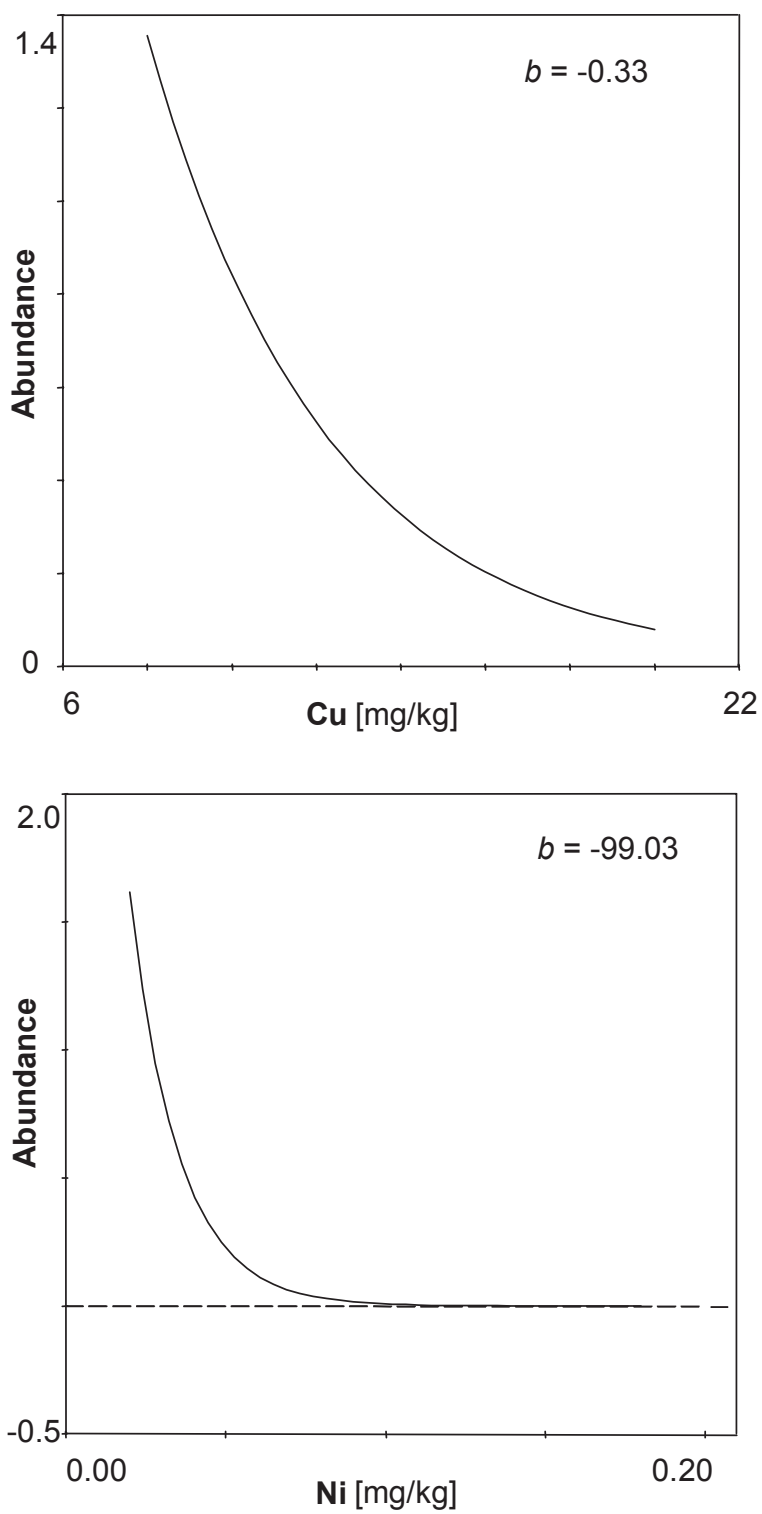

concentration was in rodents infected by nematodes (Table II; Fig. 5).

The detection limits (mean $\pm 3 \mathrm{SD}$ ) were $0.07 \mathrm{ng} \cdot \mathrm{ml}^{-1}$ for cadmium, $0.17 \mathrm{ng} \cdot \mathrm{ml}^{-1}$ for chromium, $0.69 \mathrm{ng} \cdot \mathrm{ml}^{-1}$ for copper, $0.37 \mathrm{ng} . \mathrm{ml}^{-1}$ for manganese, $0.21 \mathrm{ng} \cdot \mathrm{ml}^{-1}$ for nickel, 0.21 ng.ml-1 for lead and 6. ng. $\mathrm{ml}^{-1}$ for $\mathrm{Zn}$. Analytical data obtained for $\mathrm{Cd}$. $\mathrm{Cu}, \mathrm{Mn}, \mathrm{Pb}$ and $\mathrm{Zn}$ contents in CRM 12-02-01 (Bovine liver) were found in the confidence interval given by the producer of CRM for these elements. Values for chromium and nickel contents are not certified in this CRM.

The abundance of gastrointestinal helminths (cestoda and nematoda) and bioaccumulation of heavy metals in their livers and kidneys is also represented by Figs 6-7. The contents of $\mathrm{Cr}, \mathrm{Cu}, \mathrm{Ni}$ and $\mathrm{Zn}$ in host
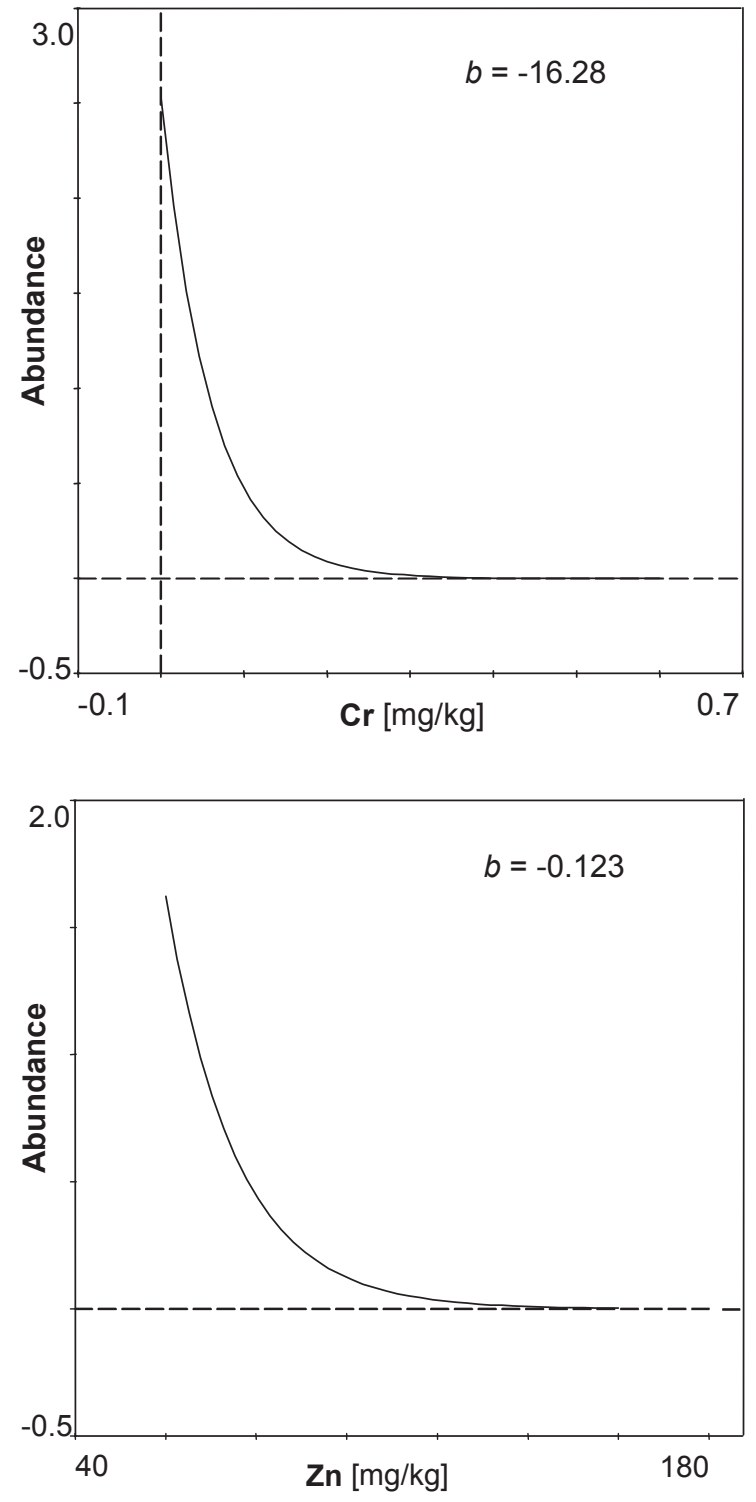

Fig. 6. - Relationship between the amount of heavy metals and the abundance of Paranoplocephala sp. in 10 Microtus agrestris (data on kidney and liver pooled). Non-linear models were obtained by GLM. All slope coefficients $(b)$ are significantly different from 0 (t-test, $\mathrm{P}<$ 0.05). 

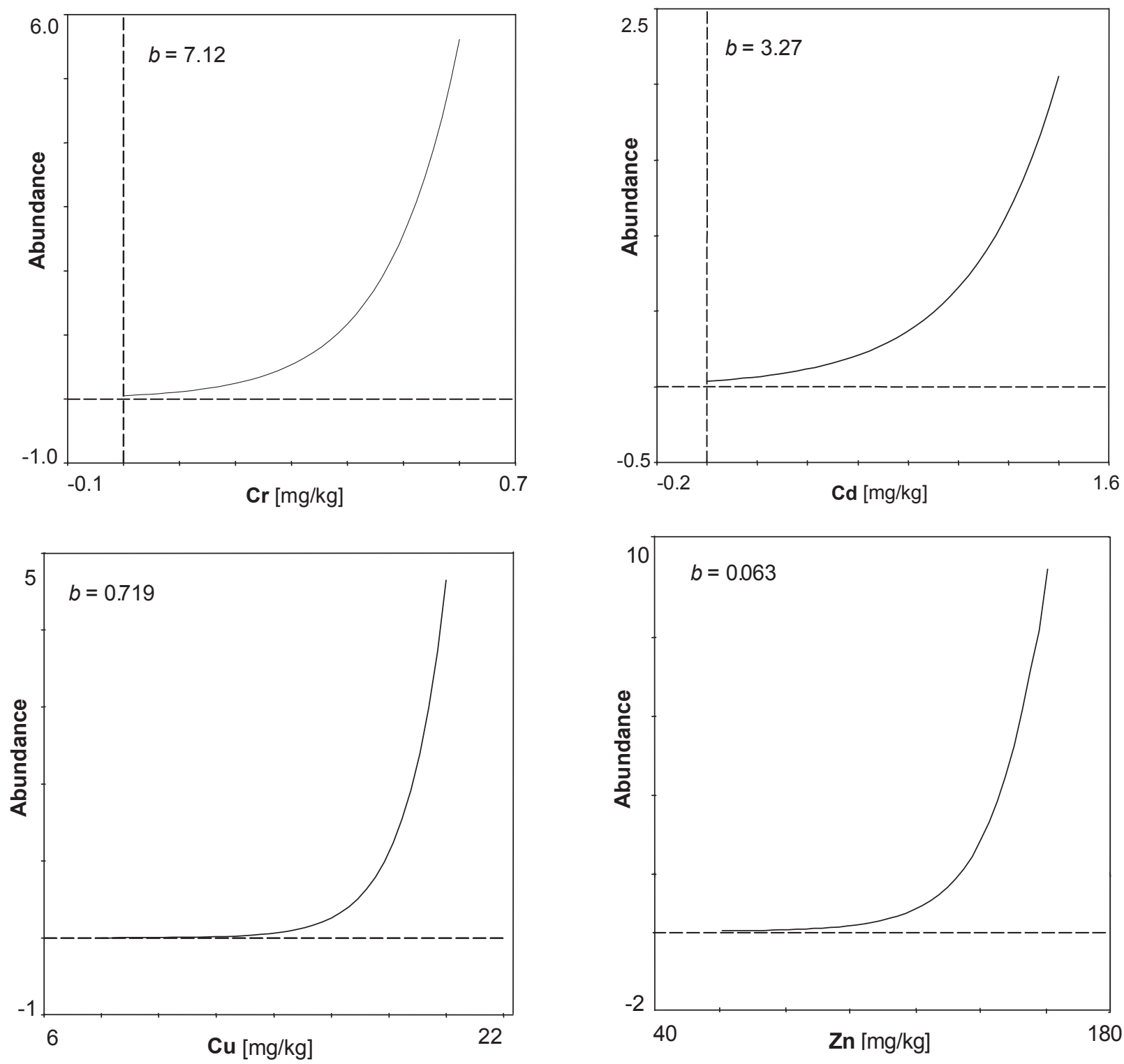

Fig. 7. - Relationship between the amount of heavy metals and the abundance of Mastophorus muris in 15 Apodemus flavicolis (data on kidney and liver pooled). Non-linear models were obtained by GLM. All slope coefficients $(b)$ are significantly different from 0 ( $\mathrm{t}$-test, $\mathrm{P}<$ 0.05).

liver or kidneys was decreasing with the increased abundancy of cestodes (Paranoplocephala sp.) in 10 field voles (Fig. 6). On the contrary, the content of $\mathrm{Cd}, \mathrm{Cr}$, $\mathrm{Cu}$ and $\mathrm{Zn}$ in host tissues increased with the abundance of nematode Mastophorus muris in 15 field mice (Fig. 7).

\section{DISCUSSION}

$\mathrm{R}$ odents used in this study were captured in industrial immission affected area of Krusne hory Mts.

(Fig. 1). One of the most important sources of environmental contamination with heavy metals is coal industry in the near city Litvínov (Fig. 2). The dust emit- ted contained zinc, copper, lead and cadmium, and this contamination may have increased the content of metals in the tissues of mammals inhabiting polluted areas. Elevated concentrations of heavy metals (Cd, Mn, $\mathrm{Pb}, \mathrm{Cu}, \mathrm{Zn})$ were found in soil samples from this area by Ieradi et al. (2003).

In this study we found out that hosts infected with cestodes had lower levels of heavy metals in kidneys and livers than hosts without cestodes, infected with nematode only (Table II; Fig. 5). The mechanism whereby cestode-infected animals accumulate less toxicants than parasite-free ones is unknown, however, among other factors it may be partially due to their lower metabolic rate (Bergey et al., 2002). 
The effect of heavy metal concentrations on parasites has been studied particularly in polluted aquatic environments (Landsberg et al., 1998; Thielen et al.; 2004; Turceková et al., 2002). Considerably less literature is available on the use of mammalian endoparasites in environmental-impact studies. Yet it is known that some parasites of the terrestrial hosts do accumulate toxic elements above values detected in the tissues of their hosts. Particularly, acantocephalans and cestodes dwelling in the intestine of their definitive host are able to accumulate effectively heavy metals (Sures et al., 2002 ab). Still it remained unclear whether high metal accumulation of the worms (cestoda, acanthocephala) affects the metal levels in the tissues of the definitive host.

The response of parasites to heavy metal contents was species specific for cestoda (Fig. 6) and nematoda (Fig. 7). Whereas the increasing abundance of cestode Paranoplocephala sp. in host results in decreasing heavy metal concentration in host liver and kidneys (Fig. 6), the nematode $M$. muris showed positive relationship with the content of heavy metals in liver and kidneys (Fig. 7).

Negative relationship may support the hypothesis that the parasites with lacking digestive tract (Cestoda, Acanthocephala) concentrate metals to a higher degree than the host tissues (Thielen et al., 2004). Why the nematode $M$. muris showed positive relationship with the content of heavy metals in liver and kidneys (Fig. 7) is unknown. Sures et al. (1998) found that concentration of lead in the digenean parasite Fasciola hepatica was in average a hundred times higher than in the muscle, kidney or liver of the host. Intestinal nematode parasites Ascaris suum, on the contrary, had the concentrations of lead and cadmium significantly lower than in their host tissues. Nematodes appear not to be suitable as sentinels, whereas a higher metal accumulation capacity is described for cestodes and especially for acanthocephalans (Lafferty, 1997). Only a few articles have been published on how mammalian nematodes accumulate heavy metals (Sures et al., 1998; Barus et al., 2001, 2003, 2007). Barus et al. (2007) report that the concentration of heavy metals was significantly higher in specimens of Philometra ovalta (Nematoda: Philometroidea) compared to the host muscle tissue. The presence of nematode parasites did not, nevertheless, influence the heavy metal content of hosts. Still, no significant differences were found between muscle tissues of parasitized and non-parasitized fishes.

Mammals are known to excrete heavy metals via their bile to their intestine. For this reason, heavy metals from the host body (host bile) cannot be absorbed by spirurid nematode $M$. muris that preferably infects the host stomach; contrary to Paranoplocephala (Cestoda: Anoplocephalidae) infecting small intestine.

Kidney is an organ in which metals are present in highest concentration for terrestrial mammals (Torres et al., 2004). Our results correspond with this (Figs 3 and 4), except for manganese that was higher in liver than in kidneys. Torres et al. (2004) assessed the concentration of cadmium and lead using a small rodent Apodemus sylvaticus and their cestode Gallegoides arfaai. They tested the potential suitability of the cestode as a sentinel organism for lead and cadmium under natural field conditions. They found out that contents of lead in the cestode were six to 24 -fold higher than in the tissues (kidney, liver and muscle) of the rodent. This shows that cestodes are able to bioconcentrate metals above the values detected in host tissues. Therefore, results from pollution test can be falsified if infected test organisms are involved.

This study presents our first results on the monitoring of heavy metal concentration in cestode or nematode infected rodents. It appears that this model including small mammals and their helminths is a promising bioindication system to evaluate environmental heavy metals exposure in terrestrial habitats.

\section{ACKNOWLEDGEMENTS}

his study was supported by a project No. 524/ 06/0687 Grant Agency of Czech Republic and MSM 6046070901 provided by the Ministry of Education, Youths and Sports. Performed experiments comply with current laws of the Czech Republic.

\section{REFERENCES}

Barus V., Jarkovsky J. \& Prokes M. Philometra ovata (Nematoda: Philometroidea): a potential sentinel species of heavy metal accumulation. Parasitology Research, 2007, 100, 929933.

Barus V. Tenora F. \& Sumbera R. Relative concentrations of four heavy metals in the parasites Protospirura muricola (Nematoda) and Inermicapsifer arvicanthidis (Cestoda) in their definitive host silvery mole-rat (Heliophobius argenteocinereus: Rodentia). Helminthologia, 2003, 40 (4), 227232.

Bergey L., Weis J.S. \& Weis P. Mercury uptake by the estuarine species Palaemonetes pugio and Fundulus beteroclitus compared with their parasites, Probopyrus pandalicola and Eustrongylides sp. Marine Pollution Bulletin, 2002, 44 (10), 1046-1050.

Han F.X., Banin A., Su Y., Monts D.L., Plodinec M.J., KinGERY W.L. \& TRIPLETT G.E. Industrial age anthropogenic inputs of heavy metals into the pedosphere. Naturwissenschaften, 2002, 89 (11), 497-504.

Ieradi L.A., Zima J., Allegra F., Kotlánová E., Campanella L., Grossi R. \& Cristaldi M. Evaluation of genotoxic damage in wild rodents from a polluted area in the Czech Republic. Folia Zoologica, 2003, 52 (1), 57-66.

KÅLÅs J.A., STEINnES E. \& LIERHAGEn S. Lead exposure of small 
herbivorous vertebrates from atmospheric pollution. Environmental pollution, 2000, 107 (1), 21-29.

LAFFERTY K.D. Environmental parasitology: what can parasites tell us about human impacts on the environment? Parasitology Today, 1997, 13 (7), 251-255.

Landsberg J.H., Blakesley B.A., Reese R.O., McRae G. \& ForstCHEN P.R. Parasites of fish as indicators of environmental stress. Environmental Monitoring and Assessment, 1998, 51 (1-2), 211-232.

Mader P., Száková J. \& Miholová D. Classical dry ashing of biological and agricultural materials. Part II. Losses of analytes due to their retention in an insoluble residue. Analusis, 1989, 26, 121-129.

ManN H.B. \& Whitney D.R. "On a test of whether one of two random variables is stochastically larger than the other". Annals of Mathematical Statistics, 1947, 18, 50-60.

R Development Core Team. A language and environment for statistical computing. R Foundation for Statistical Computing Vienna, Austria, 2004, Available at http://www.R-project.org.

Scheef G., Sures B. \& Taraschewski H. Cadmium accumulation in Moniliformis moniliformis (Acanthocephala) from experimentally infected rats. Parasitology Research, 2000, 86, 688-691.

Schludermann C., Konecny R., Laimgruber S., Lewis J.W., SchieMER F., ChOVAnec A. \& SuREs B. Fish macroparasites as indicators of heavy metal pollution in river sites in Austria. Parasitology, 2003, 126, S61-S69.

STATSOFT, INC. STATISTICA Cz, software system for data analysis, 2005, version 7.1. www.StatSoft.Cz

SuRES B. The use of fish parasites as bioindicators of heavy metals in aquatic ecosystems: a review. Aquatic Ecology, 2001, 35, 245-255.

SuRES B. Accumulation of heavy metals by intestinal helminths in fish: an overview and perspective. Parasitology, 2003, 126, S53-S60.

SuRES B. Environmental parasitology: relevancy of parasites in monitoring environmental pollution. Trends in Parasito$\log y, 2004,20,170-177$.

SuRES B. How parasitism and pollution affect the physiological homeostasis of aquatic hosts. Journal of Helmintho$\log y, 2006,80,151-157$

Sures B., Franken M. \& TARASChewski H. Element concentrations in the archiacanthocephalan Macracanthorbynchus birudinaceus compared with those in the porcine host from a slaughterhouse in La Paz, Bolivia. International Journal for Parasitology, 2000a, 30, 1071-1076.

Sures B., Grube K. \& TARaschewski H. Experimental studies on the lead accumulation in the cestode Hymenolepis diminuta and its final host, Rattus norvegicus. Ecotoxicology, 2002a, 11, 365-368.

SurES B., JÜRgES G. \& TARASCHEWSKI H. Relative concentrations of heavy metals in the parasites Ascaris suum (Nematoda) and Fasciola bepatica (Digenea) and their respective porcine and bovine definitive hosts. International Journal for Parasitology, 1998, 28, 1173-1178.

Sures B., JÜrges G. \& TARAschewsKI H. Accumulation and distribution of lead in the acanthocephalan Moniliformis moni- liformis from experimental infected rats. Parasitology, 2000b, 121, 427-433.

Sures B., Scheef G., Klar B., Kloas W. \& Taraschewski H. Interaction between cadmium exposure and infection with the intestinal parasite Moniliformis moniliformis (Acanthocephala) on the stress hormone levels in rats. Environmental Pollution, 2002b, 119, 333-340.

Sures B. \& Siddall R. Pomphorbynchus laevis: the intestinal acanthocephalan as a lead sink for its fish host, chub (Leuciscus cephalus). Experimental Parasitology, 1999, 93, 6672.

SuRES B. \& SidDALl R. Comparison between lead accumulation of Pomphorbynchus laevis (Palaeacanthocephala) in the intestine of chub (Leuciscus cephalus) and in the body cavity of goldfish (Carassius auratus auratus). International Journal for Parasitology, 2001, 31, 669-673.

Sures B., Siddall R. \& TARAschewski H. Parasites as accumulation indicators of heavy metal pollution. Parasitology Today, 1999, 15, 16-21.

Ter Braak C.J.F. \& Smilauer P. CANOCO Reference Manual and CanoDraw for Windows User's Guide. Software for Canonical Community Ordination (version 4.5). Biometris, Wageningen and Ceské Budějovice, CR, 2002.

Thielen F., Zimmermann S., Baska F., Taraschewski H. \& SuREs B. The intestinal parasite Pomphorhynchus laevis (Acanthocephala) from barbel as a bioindicator for metal pollution in the Danube river near Budapest, Hungary. Environmental pollution, 2004, 129 (3), 421-429.

Torres J., De Lapuente J., Eira C. \& Nadal J. Cadmium and lead concentrations in Gallegoides arfaai (Cestoda: Anoplocephalidae) and Apodemus sylvaticus (Rodentia: Muridae) from Spain. Parasitology Research, 2004, 94 (6), 468470 .

Turceková L., Hanzelová V. \& Spakulová M. Concentration of heavy metals in perch and its endoparasites in the polluted water reservoir in Eastern Slovakia. Helminthologia, 2002, 39 (1), 23-28.

Reçu le 5 novembre 2007 Accepté le 8 mai 2008 